\title{
A Survey Study of Students’ Opinion about Quality of Education
}

\section{Hina Kosar ${ }^{*}$, Riaz ul Haq Tariq ${ }^{2}$ and Najam ul Kashif ${ }^{3}$}

${ }^{1}$ Bahauddin Zikriya University, Multan, Pakistan

${ }^{2}$ GC University Faisalabad, Pakistan

${ }^{3}$ Bahauddin Zikriya University, Multan, Pakistan

\begin{abstract}
This article addresses the question of quality of education in undergraduate programs of Bahauddin Zakariya University Multan through views and opinions of the students. The university is running undergraduate programs for the last two decades. Quality of a program is indeed like the worth of it. The population of this work comprised 705 BS students of Bahauddin Zakariya University half of which, randomly, were taken as sample. A questionnaire was administered carrying parameters of quality of education laid down by Higher Education Commission (HEC) of Pakistan.

The opinion of the sample, as received through responses on questionnaire, was tabulated for application of statistical tools and analysis. Percentage and Mean were used as statistical applications to draw out concrete conclusions in qualitative and quantitative formats. The survey led to the facts that majority of students expressed positive opinion towards the quality of education in their respective programs.
\end{abstract}

Keywords: Students opinion; Quality of education; Undergraduate level; University

\section{Introduction}

Education is the process of teaching and learning. The set of knowledge and skill obtained through the process of education reflect the extent of quality in process of education. Undergraduate education, in the educational tier of Pakistan, is the phase of studies open after passing what is generally known as Intermediate education or Higher Secondary Education (twelve years of studies). The BZ University is running 4-Year undergraduate programs in Science, Commerce, Business, Pharmacy, Engineering, and English Literature and Linguistics. The university has established a quality enhancement cell to weigh and watch quality of work in academics and research [1-5].

The concept of quality in context of education implies multifarious aspects. Major ones are described as under: 1) Learners who are healthy, well-nourished and ready to participate and learn, and supported in learning by their families and communities; 2) Environments that are healthy, safe, protective and gender-sensitive, and provide adequate resources and facilities; 3 ) Content that is reflected in relevant curricula and materials for the acquisition of basic skills, especially in the areas of literacy, numeracy and skills for life, and knowledge in such areas as gender, health, nutrition, HIV/AIDS prevention and peace; 4) Processes through which trained teachers use child-centered teaching approaches in well-managed classrooms and schools and skilful assessment to facilitate learning and reduce disparities; 5) Outcomes that encompass knowledge, skills and attitudes, and are linked to national goals for education and positive participation in society.

This article reflects a crux as to whether and to what extent do the quality of education exists in undergraduate programs at BZ University [6-8].

The study is useful for all who are concerned with BS programs of the BZ University - the students, the faculty, and the admin of the University; and going even further and wider for the community - parents and guardians of students and feeding institutions of the university.

\section{Objective of the study}

The study is based on a single objective which aimed as how to raise awareness among students about activities and objectives of the program.

\section{Significance of the Study}

A large number of students are enrolled in undergraduate programs in the BZU Multan. The administration of any program is always concerned with the successful running of it. Delivery with quality is prime focus for the ultimate success of any program [9-13].

Students are always keen to see what a program carries, how it is being executed, which objectives are set and which means are employed to secure the success of the program.

The administration of the program needs to know the feedback of the program. This survey evaluates purpose vs. performance, course vs. content, and formation vs. function of the program. The survey is also significant for its focus on results and retention of students in the programs $[14,15]$.

For students, this survey aims to raise better information and awareness about the program and for teachers; it aims to raise weaker point and parameters of program. Ultimately, this leads to execution of improvement of the program, fulfillment of its objectives, utility of its degree and reliability of academic and research work in the program.

\section{Methodology}

\section{Population}

The population for this study comprised all students studying in all

*Corresponding author: Hina Kosar, Bahauddin Zikriya University, Multan, Pakistan, Tel: +92619210097; E-mail: hina.anwer2010@gmail.com

Received October 22, 2014; Accepted May 18, 2015; Published May 25, 2015

Citation: Kosar H, Tariq RH, Kashif N (2015) A Survey Study of Students' Opinion about Quality of Education. Arts Social Sci J 6: 099. doi:10.4172/21516200.1000099

Copyright: ( $) 2015 \mathrm{Kosar} \mathrm{H}$, et al. This is an open-access article distributed under the terms of the Creative Commons Attribution License, which permits unrestricted use, distribution, and reproduction in any medium, provided the original author and source are credited. 
undergraduate programs at the $\mathrm{BZ}$ university. There are 6 departments in the university where undergraduate programs are in progress; those are Social Sciences Departments (Economics, Education, and Sociology) and Natural Sciences Departments (Chemistry, Physics, Zoology). These departments are educating a total of 705 students in their undergraduate programs. So the population of this survey comprises 705 undergraduate students.

\section{Sample}

This survey was conducted with a sample of 310 students out of the given population of afore mentioned departments of the university.

\section{Development of instrument}

Keeping in view the workability and suitability of the project, a scale for Students was framed. This scale was utilized to study the trends and tendencies among the students. In addition to this scale, necessary documents were also being consulted to go through the implicit information on the topic.

\section{Framework of item development}

The items for the instrument i.e. questionnaire were developed on the basis of criteria to determine quality of a program as laid down in the HEC Manual titled as 'Self Assessment Manual' prepared by Dr. Abdul Raouf and approved by QAC (Qualify Assurance Committee) of HEC. The criteria of quality of program are summed up as under:

Program mission, objectives and outcomes: 1) The program must have measureable objectives supporting Faculty/college and institution mission statements. 2) The program must have documented outcomes for students and make them capable of performing these outcomes. 3) The results of program's assessment and the extent to which they are used to improve the program must be documented. 4) The department must assess its overall performance periodically using quantifiable measures.

Curriculum design and organization: 1) The curriculum must be consistent and support the program's documented objectives. 2) Theoretical background, problems analysis and solution design must be stressed within the program's core material. 3) The curriculum must satisfy the core and major requirements for the program as specified by the respective accreditation body, councils, HEC. 4) The curriculum must satisfy the general education, arts, and professional and other discipline requirements for the program as specified by the respective accreditation body, councils, HEC. 5) Information technology component of the curriculum must be integrated throughout the program. 6) Oral and written communication skills of the students must be developed and applied in the program.

Laboratories and computing facilities: 1) Laboratory manuals / documentation / instructions for experiments must be available and readily accessible to the faculty and students. 2) There must be adequate support personnel for instruction and maintaining the laboratories. 3) The university computing infrastructure and facilities must be adequate to support program's objectives.

Student support and guidance/advising: 1) Courses must be offered with sufficient frequency and number for students to complete the program in a timely manner. 2) Courses in the major area of study must be structured to ensure effective interaction between students, faculty and teaching assistants. 3) Guidance on how to complete the program must be available to all students and access to academic advising must be available to make course decisions and career choices.
Faculty: 1) There must be full time faculty for adequate coverage of the program areas / courses with continuity and stability. The interest and qualifications of all faculty members must be sufficient to teach all courses, plan, modify and update courses and curricula. 2) All faculty members must remain current in the discipline and sufficient time must be provided for scholarly activities and professional development Also effective programs for faculty development must be in place. 3) All faculty members should be motivated and have job satisfaction to excel in their profession.

Process control: 1) The process by which students are admitted to the program must be based on quantitative and qualitative criteria and clearly documented. This process must be periodically evaluated to ensure that it is meeting its objectives. 2) The process by which students are registered in the program must be documented; and monitoring of students' progress to ensure timely completion of the program must be documented. This process must be periodically evaluated to ensure that it is meeting its objectives. 3) The process of recruiting and retaining highly qualified faculty member must be in place and clearly documented. Also processes and procedures for faculty evaluation, promotion must be consistent with institution mission statement. These processes must be periodically evaluated to ensure that meeting of objectives. 4) The process and procedures used to ensure that teaching and delivery of course material to the students emphasizes active learning and that course learning outcomes are met. The process must be periodically evaluated to ensure that it is meeting its objectives. 5) The process that ensures that graduates have completed the requirements of the program must be based on standards, effective and clearly documented procedures. This process must be periodically evaluated to ensure that it is meeting its objectives.

Institutional facilities: 1) The institution must have in the infrastructure to support new trends in learning such as e-learning. 2) The library must possess an up-to-date technical collection relevant to the program and must be adequately staffed with professional personnel. 3) Classrooms must be adequately equipped and offices must be adequate to enable faculty to carry out their responsibilities.

Institutional support: 1) There must be sufficient support and financial resources to attract and retain high quality faculty and provide the means for them to maintain competence as teachers and scholars. 2) There must be an adequate number of high quality graduate students, research assistants and Ph.D. students. 3) Financial resources must be provided to acquire and maintain library holdings, laboratories and computing facilities.

\section{Collection and Analysis of Data}

Through email and phonic follow-up, data was collected personally by the researcher to secure maximum back receipt of questionnaires. The data was analyzed on 5- point likert scale to stay most close and accurate in terms of reliability and vitality of the process/project.

\section{Statistical analysis}

The results were recorded on a master-sheet and then tabulated. To distinguish the impact of responses from the students, percentage and mean were used as statistical appliances to reach concrete conclusions. To obtain mean score for each statement, the following formula was applied:

Mean Score $=$ FSA x $5+$ FA X $4+$ FUD $\times 3+$ FDA X $2+$ FSDA X 1 Divided by Total Nos. $=\mathrm{N}$

Where 
FSA $=$ Frequency of the Responses in 'Strongly Agree'

1) For negative statements the order was-reversed.

2) As the norm for each statement is 3 , the mean score more than 3.00 shows approval or agreement to the statement, while a mean score less than 3.00 shows the disapproval or disagreement to the statement (Tables 1-5).

\section{Findings and Discussion}

Out of the survey, it came out that:

1) $85.82 \%$ students were agreed that they are aware of programs

\begin{tabular}{|c|c|c|}
\hline Variable & \multicolumn{2}{|c|}{ Category } \\
\hline \multirow{3}{*}{ Gender } & Male & Female \\
\cline { 2 - 3 } & 217 & 488 \\
\cline { 2 - 3 } & Total & 705 \\
\hline
\end{tabular}

Table 1: Demographic Profile of Students' Population.

\begin{tabular}{|c|c|c|c|c|c|}
\hline \multirow{4}{*}{} & \multirow{3}{*}{ Under-Graduate } & \multicolumn{4}{|c|}{ Semester } \\
\cline { 2 - 6 } & & $\mathbf{3 r d}$ & $\mathbf{5}^{\text {th }}$ & $\mathbf{7 t h}$ & Total \\
\cline { 2 - 6 } & Economics & 38 & 38 & 32 & 108 \\
\cline { 2 - 6 } Program & Zoology & 38 & 29 & 38 & 105 \\
\cline { 2 - 6 } & Sociology & 21 & 27 & 35 & 83 \\
\cline { 2 - 6 } & Education & 28 & 30 & 27 & 85 \\
\hline & Physics & 60 & 47 & 34 & 141 \\
\hline & Chemistry & 70 & 50 & 63 & 183 \\
\hline
\end{tabular}

Table 2: Semester wise Demographic Profile of Students' Population.

\begin{tabular}{|c|c|c|}
\hline Variable & \multicolumn{2}{|c|}{ Category } \\
\hline \multirow{3}{*}{ Gender } & Male & Female \\
\cline { 2 - 3 } & 87 & 223 \\
\cline { 2 - 3 } & Total & 310 \\
\hline
\end{tabular}

Table 3: Demographic Profile of Students' Sample.

\begin{tabular}{|c|c|c|c|c|c|}
\hline \multirow{4}{*}{ Under-Graduate } & \multicolumn{4}{|c|}{ Semester } \\
\cline { 2 - 5 } & Economics & 3rd & $\mathbf{5}^{\text {th }}$ & $\mathbf{7 t h}$ & Total \\
\cline { 2 - 5 } & Zoology & 23 & 21 & 13 & 52 \\
\cline { 2 - 6 } & Sociology & 13 & 19 & 15 & 52 \\
\cline { 2 - 6 } & Education & 17 & 13 & 20 & 50 \\
\cline { 2 - 6 } & Physics & 27 & 13 & 11 & 51 \\
\cline { 2 - 6 } & Chemistry & 28 & 13 & 14 & 55 \\
\hline
\end{tabular}

Table 4: Semester wise Demographic Profile of Students' Sample.

\begin{tabular}{|c|c|c|}
\hline S. No. & Statement & $\begin{array}{l}\text { Mean } \\
\text { Score }\end{array}$ \\
\hline 1 & Awareness of students about the program objectives & 3.9 \\
\hline 2 & Sufficiency of resources for IT and libraries. & 3.5 \\
\hline 3 & Well-equipped and finely furnished classrooms for the program. & 3.8 \\
\hline 4 & Availability of sufficient full time faculty for the program. & 3.1 \\
\hline 5 & $\begin{array}{l}\text { Availability of suitable guidance and counseling system for } \\
\text { students. }\end{array}$ & 3.5 \\
\hline 6 & $\begin{array}{l}\text { Placement of adequate support personnel for maintenance of } \\
\text { labs. }\end{array}$ & 3.1 \\
\hline 7 & Efficient administration \& management of the program & 3.4 \\
\hline 8 & $\begin{array}{l}\text { Proper alignment of courses of studies with objectives of } \\
\text { programs. }\end{array}$ & 3.5 \\
\hline 9 & Implementation of IT components of the curriculum in program. & 3.4 \\
\hline 10 & Conduct of ample of research work and activities in the program. & 3.1 \\
\hline
\end{tabular}

Table 5: Item-wise Mean Scores. objectives. 2) $61.28 \%$ students were agreed to the statement about extensive laboratory work is carried out in the under-graduate program. 3) $66.44 \%$ students were in favor of faculty for the program is highly qualified. 4) $61.28 \%$ students were in favor of that there is suitable guidance and counselling system for the students. 5) $40.32 \%$ students were believed that adequate support personnel are in position for maintaining the lab. 6) $55.82 \%$ students were in favor of that there is ample of research work activities in the program. 7) $65.50 \%$ students were satisfied with administration of the program is overall fine/satisfactory. 8) $50.01 \%$ students believed that most of students are satisfied with curriculum design and organization of the program. 9) $66.79 \%$ students were in favor of that the courses of studies are well aligned with objectives of the programs. 10) $21.05 \%$ students were in favor of the program does carry IT components of the curriculum.

It is widely acknowledged that education is a means to develop the people of any society to get and stay fit in their specific social life. This work has served as an attempt to study the existing practices of quality of education at undergraduate level at BZU and the developing further activities to promote and practice quality of education. This study has brought out occasions and opportunities of better educational life among the rising citizens of the country i.e. undergraduate level students and makers of good citizens i.e. teachers. The scope was studied within the educational community of the city of Multan (at BZU students of undergraduate level). It is generally supposed that our educational system is not formally focusing quality of education, despite acknowledging that quality of education contribute towards a better educational life not only for themselves but for their fellow citizens also.

This work was done for a population of undergraduate level students. The sample group comprised 310 students and six programs of study from BZU. These students were selected on random selection basis. From each program 50 to 52 undergraduate level students were taken. The instrument plied for the work wasscale for students. This scale was got validated from the high profile University experts. The scale comprised 21 items. Each item had 5-level response options (Strongly Agreed - Agreed - Undecided - Disagreed - Strongly Disagreed). Score of options was assigned between 5 (Max) to 1 (Min.). This instrument was administered on the sample of students. Retrieval of scale was $100 \%$. The data received through the research instrument was analyzed on 5-Point Likert Scale. The responses were treated initially on master sheet and then in tabulation. Statistical treatment of percentage and Mean was plied to reach concrete conclusions.

Mean Score $=$ FSA X $5+$ FA X $4+$ FUD X $3+$ FDA X $2+$ FSDA X 1 Divided by Total Nos. $=\mathrm{N}$

Analysis of data collected through the instrument was done on the basis of Statement analysis.

\section{Conclusion}

Analysis of the data reveals that majority of the students showed highly positive attitude towards quality of education programs. Similarly, acceptance level of the students for quality of education programs was high that showed their inclination towards quality of education. However, overall statement analysis showed that sample groups viz. students agreed to most of the statements of the scales. This reveals that they have favored and supported the programs of quality of education. As the mean score in many cases was higher than the norm (3.00) so the hypothesis was accepted. 
Citation: Kosar H, Tariq RH, Kashif N (2015) A Survey Study of Students' Opinion about Quality of Education. Arts Social Sci J 6: 099. doi:10.4172/21516200.1000099

\section{Recommendations}

1) No of statements in the scales should be increased so that more factors regarding quality of education could be covered.

2) The sample of students may be enhanced so that the opinions about the Quality of education may be sought from a larger sample.

3) This study is delimited to under-Graduate level. Future studies can include Graduate level, or Post-Graduate level.

4) This study is delimited to students of BZU. Future research can include students of other Universities of Multan/Punjab.

\section{References}

1. Abedor HW (1987) Quality Teaching. University of Michigan, Michigan.

2. Arcaro BK (1987) Talking Higher Education. Clifford Publishing, Philadelphia.

3. Bassey MA (1999) Case Study Research in Educational Settings. Open University Press, Buckingham.

4. Dean KL (1984) Counseling for the Next Step. Oxford University Press, Oxford.

5. Govt. of Pakistan (1999) Educational Policy Revised Version. Federal Bureau of Curriculum, Islamabad.
6. Hamidullah MS (2005) Comparison of the Quality of Higher Education in Public and Private Sector Institutions in Pakistan. University of Arid Agriculture, Rawalpindi.

7. ICBSE (1995) Emerging Trends in Secondary Education. CBSE Press, New Delhi.

8. Jacob RE (1979) Education in Graduation. Edwin Press, Aukland.

9. Liston KD (1999) When Quality Matters. Cambridge University Press Cambridge.

10. McArthy MM (1997) Formation of Quality Program. Journal of Educationists, Misochusites 11: 25-26.

11. Murnane GR (1987) Education for Society. Winston Press, Melbourne.

12. Rao RM (2003) Undergraduate Programmes in Karachi University. Jamshoro University, Jamshoro.

13. Raouf A (2006) HEC Self-Assessment Manual. HEC, Lahore: 16-20.

14. Saqib SZ (2007) A Study to Investigate the Quality of Education at Intermediate Level in Punjab. University of Arid Agriculture, Rawalpindi.

15. UNESCO (1990) Report on Education in Asia. UNO Journal, New York 12 97-102. 